\title{
Progressive Agriculture
}

Journal homepage:http://www.banglajol.info/index.php/PA

\section{Economic assessment of lemon-based agroforestry systems established in Madhupur Sal forest area of Bangladesh}

\author{
MK Hasan*, GMM Rahman, R Akter, SAK Hemel, MT Islam
}

Department of Agroforestry, Bangladesh Agricultural University, Mymensingh 2202, Bangladesh.

\begin{abstract}
The study was carried out to determine the economic assessment of lemon-based agroforestry systems established in the Madhupur Sal forest during the period from May 2017 to September 2018. The study selected five lemon-based agroforestry systems viz. Lemon-Mango-Pineapple-Papaya-Ginger, Lemon-Pineapple-Papaya-Banana-Aroid, Lemon-Pineapple-Papaya-Ginger, Lemon-Mango-Turmeric-Red amaranth and Lemon-Litchi-Papaya-Banana along with three replications having 0.13 ha area for each sample plot. The control plots (without lemon plant) for each of the five lemon-based agroforestry systems were also selected. In order to calculate the economic profitability of respective agroforestry systems as well as sole cropping performance, data related to incurred cost, total yield and income from lemon and crop components were collected through practical observation, key informant interview and focus group discussion. The benefit-cost ratio (BCR) and land equivalent ratio (LER) for each of the selected agroforestry systems were also determined. From the study, it has been found that all of the lemon-based agroforestry systems were profitable than their sole cropping in respect of income, BCR, and LER. The net profit (460032 Tk/ha) indicated that the Lemon-Litchi-Papaya-Banana based agroforestry systems were financially more profitable followed by Lemon-Pineapple-Papaya-Banana-Aroid, Lemon-Mango-Pineapple-Papaya-Ginger, LemonPineapple-Papaya-Ginger, Lemon-Mango-Turmeric-Red amaranth based agroforestry systems. But the BCR and LER (3.515 and 1.73) revealed that Lemon-Pineapple-Papaya-Banana-Aroid based agroforestry system was more productive followed by Lemon-Litchi-Papaya-Banana, Lemon-Mango-Pineapple-Papaya-Ginger, Lemon-PineapplePapaya-Ginger, Lemon-Mango-Turmeric-Red amaranth based agroforestry systems. Prior to considering the obtained results from the study, it can be concluded that lemon-based agroforestry systems are more profitable than the cultivation of sole cropping.
\end{abstract}

Key words: Agroforestry, lemon, cost of production, BCR, LER

Progressive Agriculturists. All rights reserved

*Corresponding Author: mkhasanaf@bau.edu.bd

\section{Introduction}

Forest is an important natural resource of any country requiring $25 \%$ forest land of the total area of the country for its socio-economic upliftment and maintenance of environmental equilibrium. Of the total geographic area of Bangladesh, agricultural land makes up $65 \%$ and forest land accounts only $17.08 \%$; while urban areas cover $8 \%$ of the land (FAO, 2015; BFD,
2017; BBS, 2014). In Bangladesh, the Sal forests are one of the three most important forest resources (other kinds are tropical evergreen and coastal forests) covering an area of about 120,000 ha which money owed about $0.81 \%$ of the whole land and $7.5 \%$ forest insurance. Sal (Shorea robusta) is the dominant species 


\section{Economic assessment of lemon-based agroforestry}

of this woodland and usually forms $75-90 \%$ of the upper canopy in the natural habitat (BFD, 2017).

The Madhupur Sal forest is representing the major patches of Bangladesh Sal forests which are valuable in ecological as well as economic aspects that have been degraded due to destructive anthropogenic activities. About 50,000 forest-dependent households including ethnic minorities are living in and around 21 villages of this forest area (Islam et al., 2012, 2013, 2015). The local farmer of the Madhupur Garh area relies on agroforestry practices that play a vital role in offering multiple alternatives and opportunities with a view to improving farm production and income and also providing productive and conservation functions to the ecosystems (Alam et al., 2010). Some researchers have noted the benefits of Mango, Banana, Pineapple, Lemon, Jackfruit, and different seasonal crops cultivation along with agroforestry practices at the Madhupur Garh area (Akter et al., 2020; Rana, 2017; Kibria and Saha, 2011; Roy et al., 2011; Hasan et al., 2008; Safa, 2004). Farmers of Bangladesh, like many other Asian countries, have been growing cereals, root crops, fiber, vegetables, and fruit in association with the trees and another woody perennial (Alam et al., 1990).

Scientists and experts have worked with farmers throughout the world to identify and develop improved agroforestry practices that build on local practices and offer substantial benefits to communities and to the environment (Franzel and Scherr, 2002). The most important crop and tree products from the Madhupur Garh areas agroforestry practices are Pineapples, Ginger, Aroid, Turmeric, Banana, Papaya and poles, pulpwood and firewood as these trees are mostly shortrotation species (Ghosh et al., 2011; Islam et al., 2013; Chakraborty et al., 2015; Kibria and Saha, 2011). In Bangladesh, it is revealed that about $2 \%$ family income comes from Agroforestry practices (Chakraborty et al., 2015); however, the agroforestry programs at the Madhupur Sal forest area contributed more than 46\% of the forest dependents people's household income (Islam et al., 2011).

According to past research evidence, Akter et al. (2020) conducted research in Madhupur Sal forest on productivity analysis of timber and fruit tree-based agroforestry practices where they found that integrated agroforestry systems are more productive than monoculture. In addition to that in Narsingdi district, Jackfruit and Egg-plant based agroforestry practices showed that the positive result in the case of BCR and LER (Rahman et al., 2017). Again Lemon, Pineapple, and Banana-based agroforestry systems practiced in private or participatory programs are also profitable (Kibria and Saha, 2011). Hasan and Karim (2020) found that agroforestry practices are more economically profitable than the cultivation of their non-agroforestry systems in the case of Eucalyptus and Gamar based agroforestry practices. However, the number of research studies related to productivity evaluation of timber and fruit tree-based agroforestry systems were studied in the Madhupur Sal forest area but the economic aspects of Lemon based agroforestry systems in the study area was negligible. Therefore, considering the aforementioned facts, this piece of research work has been taken with the objective of evaluating the economic assessment of Lemon based agroforestry systems established in the Madhupur Sal forest of Bangladesh.

\section{Materials and Methods}

Geographical description of the study area: The Madhupur Sal forest lies between $23^{\circ} 50^{\prime}$ to $24^{\circ} 50^{\prime}$ North latitude and $89^{\circ} 54^{\prime}$ to $90^{\circ} 50^{\prime}$ East longitude (Figure 1). The total area of Madhupur Sal forest is about 18447.44 ha. The topography of the area is characterized by plain land and low hills rising 3.0-4.5 $\mathrm{m}$ above the surrounding field locally known as 'chalas', which are intersected by numerous depressions or 'baids'. The soils are characterized by low organic matter and low fertility. The annual rainfall ranges from $203-229 \mathrm{~cm}$ and the annual temperature ranges from $10-34^{\circ} \mathrm{C}$. The humidity of the areas varies from 60 to $86 \%$ (Hasan et al., 2016).

Specific study area and sampling design: Administratively Madhupur Sal forest comprising four ranges namely Madhupur National Park, Dokhla, 
Arunkhola, and Madhupur (Rahman et al., 2013). The study was conducted in the three villages namely Gaira, Jolai and Magontinagor of Madhupur Sal forest were selected for the study area because Lemon-based agroforestry systems are dominant in this area (Figure 1). The study was carried out from May 2017 to September 2018 under the competitive research grant
(CRG) sub-project of the National Agricultural Technology Project Phase-2 (NATP-2) coordinated by BARC. This study dealt with five different Lemons based existing agroforestry systems with three replications having a 0.13 ha area for each sample plot along with a control plot (except tree) for each combination. The total numbers of plots were 30 .

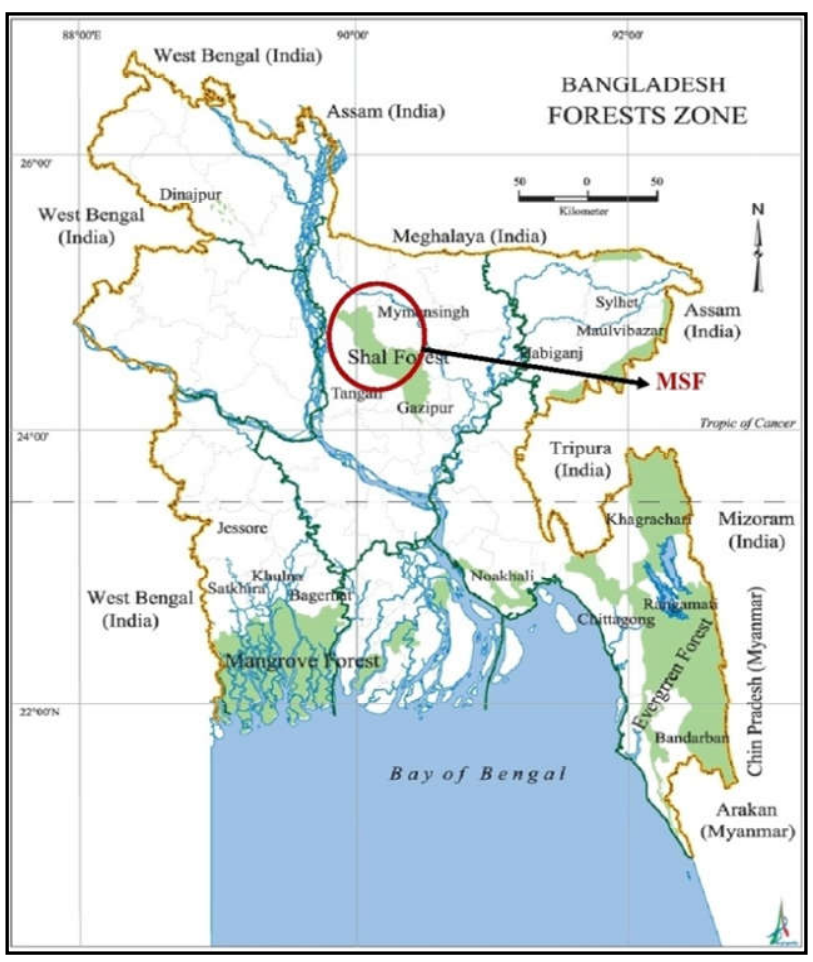

A

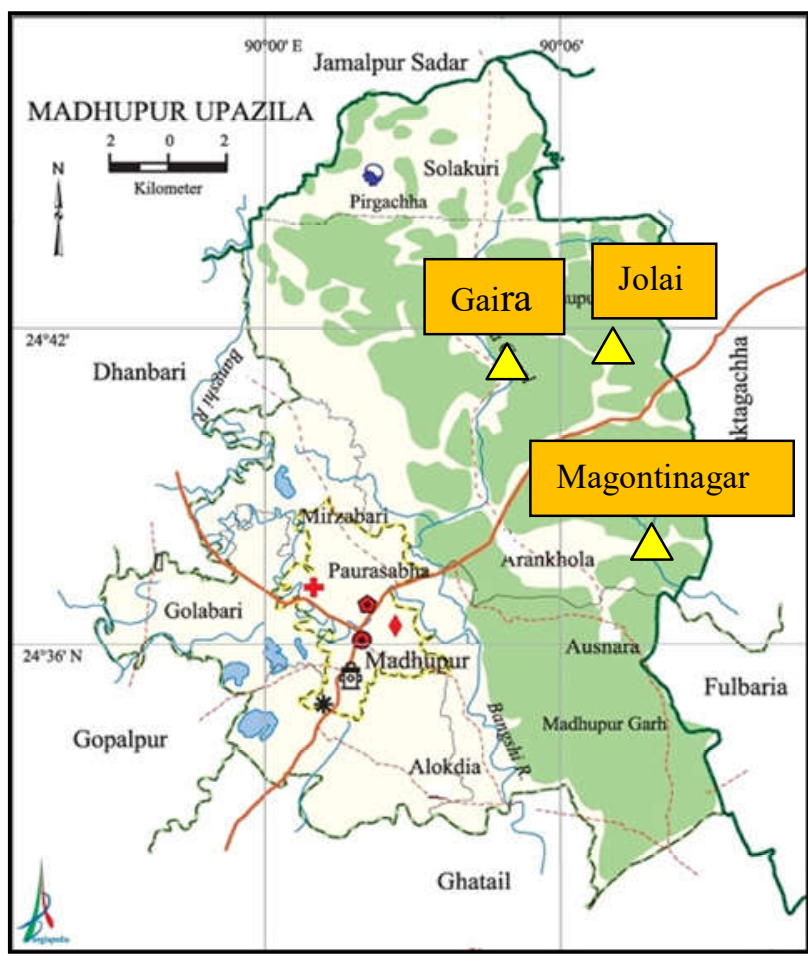

B

Fig. 1. Bangladesh forest map showing Madhupur Sal Forest (MSF) (A) (Source: Banglapedia, 2015a) and a map of Madhupur Upazila of Tangail district representing the study locations (B) (Source: Banglapedia, 2015b)

Selection of lemon-based agroforestry practices: The following five lemons based established agroforestry systems along with their control (without lemon plant) were selected randomly through secondary data, practical observation and consult with the community people in the study area (Table 1).

Collection of data from the selected plots: From each selected plots, the following parameters of crops and shrubs/trees were collected through practical observation, key informant interview and focus group discussion.

Crop parameters: In order to calculate crop produce, following parameters like the number of fruits/plant, the weight of fruits/plant $(\mathrm{kg})$, fruits price $(\mathrm{Tk} / \mathrm{kg})$, crop price $(\mathrm{Tk} / \mathrm{kg})$, cost of production $(\mathrm{Tk} / \mathrm{ha})$, income $(\mathrm{Tk} / \mathrm{ha})$ and crop yield (Tk/ha) was recorded. 
Shrubs/tree parameters: The productivity of tree components was measured by collecting the following parameters- number of lemon plant/plot, number of fruits/lemon plant or tree, the weight of fruits/lemon plant or tree $(\mathrm{kg})$, fruit price $(\mathrm{Tk} / \mathrm{kg})$, cost of production $(\mathrm{Tk} / \mathrm{ha})$, income $(\mathrm{Tk} / \mathrm{ha})$ and tree yield $(\mathrm{Tk} / \mathrm{ha})$.
Economic assessment of lemon based agroforestry systems: In order to perform an economic assessment of the selected lemon-based agroforestry practices and their control plots; investment analysis was carried out considering the timing of benefit and cost during the study period.

Table 1. A list of selected lemon-based agroforestry systems with their control (without lemon plant) systems.

\begin{tabular}{|l|l|l|}
\hline Cropping systems & Combinations & Plot number \\
\hline Agroforestry systems & Lemon-Mango-Pineapple-Papaya-Ginger & 3 \\
\cline { 2 - 3 } & Lemon-Pineapple-Papaya-Banana-Aroid & 3 \\
\cline { 2 - 3 } & Lemon-Pineapple-Papaya-Ginger & 3 \\
\cline { 2 - 3 } & Lemon-Mango-Turmeric-Red amaranth & 3 \\
\cline { 2 - 3 } & Lemon-Litchi-Papaya-Banana & 3 \\
\hline Control plot (without lemon plant) & Mango-Pineapple-Papaya-Ginger & 3 \\
\cline { 2 - 3 } & Pineapple-Papaya-Banana-Aroid & 3 \\
\cline { 2 - 3 } & Pineapple-Papaya-Ginger & 3 \\
\cline { 2 - 3 } & Mango-Turmeric-Red amaranth & 3 \\
\cline { 2 - 3 } & Litchi-Papaya-Banana & 30 \\
\hline Total & & \\
\hline
\end{tabular}

Procedure for determination of cost of production: The farmers practicing lemon-based agroforestry systems had to incur costs for different inputs, which were used in the production process. In order to calculate the production cost, the costs of various components like labor, seedlings or planting materials, manure or mulch, fertilizer, transport, and other related costs were collected from the farmer.

Procedure for determination of component income: The lemon plant bear fruits at the age of 2 years if perfectly hardened saplings are planted. At the age of 4 years, lemon becomes fully matured to give maximum production. To calculate the income obtained from the selected plots, the price of each component will be collected according to the selling price from the farmer.

Determination of total income: The total income of the individual agroforestry systems was computed by multiplying the total yield of components (tree and crops) with their market price.

Total income $=$ Total yield $\times$ Market price
Determination of net return: The net return of the individual agroforestry systems were computed by subtracting the total cost of agroforestry components from the total income or gross income.

Net return $=$ Total income - Total cost of production

Calculation of benefit-cost ratio (BCR): In this study, the benefit-cost ratio was estimated by using the following formula:

Benefit-cost ratio $(\mathrm{BCR})=$ Gross benefit $\div$ Cost

The BCR greater than 1 indicates that the land-use system is profitable.

Calculation of land equivalent ratio (LER): The land equivalent ratio (LER) is the ratio of the area under sole cropping to the area under intercropping needed to give equal amounts of yield at the same management level. It is the sum of the fractions of the intercropped yields divided by the sole-crop yields. In this study, the LER was calculated according to the following formula:

LER $=\mathrm{C}_{\mathrm{i}} / \mathrm{C}_{\mathrm{s}}+\mathrm{T}_{\mathrm{i}} / \mathrm{T}_{\mathrm{s}}$ 
Where,

$\mathrm{C}_{i}=$ crop yield under intercropping

$\mathrm{C}_{s}=$ crop yield under sole cropping

$\mathrm{T}_{i}=$ tree yield under intercropping, and

$\mathrm{T}_{s}=$ tree yield under sole cropping.

If $\mathrm{LER}=1$, there is no advantage (i.e., neutral) to intercropping or agroforestry in comparison to sole cropping. If LER $>1$, indicate better use of resources or positive interaction between the components. If $\mathrm{LER}<1$, indicate the competition i.e., negative interactions between the components.

Data analysis: The obtained data were scrutinized and edited before putting the data in analyzing sheets. Then data were entered into the computer and analyzed by using the MS Excel software package. The obtained data were scrutinized and edited before putting the data in analyzing sheets. Then data were entered into the computer and analyzed by using SPSS and MS Excel.

\section{Results and Discussion}

Economic assessment of lemon-based agroforestry systems

Lemon-mango-pineapple-papaya-ginger based agroforestry system: The result showed that the incurred cost of production of lemon-mango-pineapple-papayaginger based agroforestry systems for the year of 2017 and 2018 were Tk. $118700 \mathrm{ha}^{-1}$ and Tk. $58390 \mathrm{ha}^{-1}$ respectively where the initial cost of establishment of the Lemon-Mango-Pineapple-Papaya-Ginger based agroforestry system was the highest of Tk. $118700 \mathrm{ha}^{-1}$ in the year 2017 which was reduced in the next year of production Tk. 58390 ha $^{-1}$ (Table 2). The result also showed that the total yield of Lemon-PineapplePapaya-Ginger based agroforestry systems was Tk. $305260 \mathrm{ha}^{-1}$ and $260240 \mathrm{ha}^{-1}$ for the year 2017 and 2018 respectively with a total yield of Tk. $565500 \mathrm{ha}^{-1}$ (Table 2). The benefit-cost ratio (BCR) of LemonMango-Pineapple-Papaya-Ginger based agroforestry systems was 3.193 during 2017-2018 which clearly indicated that this agroforestry system was much more profitable than sole cropping (Table 2). The result also showed that Land Equivalent Ratio (LER) of LemonMango-Pineapple-Papaya-Ginger based agroforestry systems was 1.62 during 2017-2018 (Table 2). In accordance with the obtained result of LER of LemonMango-Pineapple-Papaya-Ginger based agroforestry systems, LER more than 1 indicated that LemonMango-Pineapple-Papaya-Ginger based agroforestry systems are profitable. Rahman et al. (2017) found similar findings in the case of fruit tree-based agroforestry systems which clearly indicated that combined production of the sweet gourd with mango, guava, jujube, and lemon was profitable than sole cropping. The benefit-cost ratio of fruit-tree based agroforestry practice, ginger, maize with sweat potato and teff with taro sequential monocropping was 7.22 , 2.92, and 2.88 and respectively. From this fruit-tree based agroforestry practice has higher BCR than other monocropping land uses. This implies that fruit-tree based agroforestry practice has more profitable land use than the monocropping system which was found by Anshiso et al. (2017).

Lemon-pineapple-papaya-banana-aroid based agroforestry system: The result showed that the cost of production of the Lemon-Pineapple-Papaya-BananaAroid based agroforestry system for 2017 and 2018 year was Tk. $113470 \mathrm{ha}^{-1}$ and Tk. $57690 \mathrm{ha}^{-1}$ respectively were the highest (Tk. $113470 \mathrm{ha}^{-1}$ ) in the year 2017 which was reduced in the next year of production (Table 2). The result showed that the total yield of Lemon-Pineapple-Papaya-Banana-Aroid based agroforestry systems was Tk. $332500 \mathrm{ha}^{-1}$ and 269050 $\mathrm{ha}^{-1}$ for the year 2017 and 2018 respectively with a total yield of Tk. $601550 \mathrm{ha}^{-1}$ (Table 2). The benefitcost ratio (BCR) of Lemon-Pineapple-Papaya-BananaAroid based agroforestry systems was 3.515 which clearly indicated that this agroforestry system was profitable than sole cropping. The result showed that the Land Equivalent Ratio (LER) calculated from 2017 to 2018 of the Lemon-Pineapple-Papaya-Banana-Aroid based agroforestry system was 1.73 (Table 2). In accordance with the obtained result of LER of LemonPineapple-Papaya-Banana-Aroid based agroforestry system, LER more than 1 indicated that this agroforestry system is profitable. Akter et al. (2020) found similar results for BCR and LER (2.88 and 1.58 respectively) in the case of the Akashmoni-Ginger- 
Banana based agroforestry system. Rahman et al. (2018) found that higher net return, BCR and LER from jackfruit based agroforestry system were BDT
557863, 4.56 and 2.17 respectively than their sole cropping systems in the Narsingdi district of Bangladesh.

Table 2. An economic assessment of selected lemon-based agroforestry systems.

\begin{tabular}{|c|c|c|c|c|c|c|}
\hline Economic & ers & 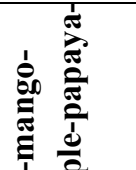 & 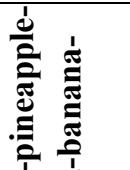 & 亗 & 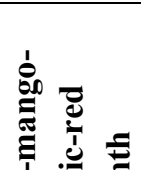 & 承 \\
\hline 4.ำ & 2017 & 118700 & 113470 & 79096 & 71560 & 121731 \\
\hline $\overrightarrow{0}$ & 2018 & 58390 & 57690 & 42840 & 31066 & 61737 \\
\hline 䓊 & Total & 177090 & 171150 & 121935 & 183468 & 183468 \\
\hline$\Xi$ & 2017 & 305260 & 332500 & 158250 & 121890 & 325130 \\
\hline$\stackrel{d}{D}$ & 2018 & 260240 & 269050 & 181290 & 148010 & 318370 \\
\hline U & Total & 565500 & 601550 & 339540 & 269900 & 643500 \\
\hline & 2017 & 186560 & 219030 & 79154 & 50330 & 203399 \\
\hline$\stackrel{\Xi}{ \pm}$ & 2018 & 201850 & 211360 & 138450 & 116944 & 256633 \\
\hline & Total & 388410 & 430390 & 217604 & 167274 & 460032 \\
\hline BCR & & 3.193 & 3.515 & 2.785 & 2.63 & 3.507 \\
\hline LER & & 3.68 & 1.73 & 1.60 & 1.59 & 1.72 \\
\hline
\end{tabular}

\section{Lemon-pineapple-papaya-ginger based agroforestry} system: From the result, it showed that the cost of production of the Lemon-Pineapple-Papaya-Ginger based agroforestry system during 2017 and 2018 year was Tk. $79069 \mathrm{ha}^{-1}$ and Tk. $42840 \mathrm{ha}^{-1}$ respectively and the total cost was Tk. $121935 \mathrm{ha}^{-1}$ during 2017-2018 (Table 2). The result also showed that the total yield of the Lemon-Pineapple-Papaya-Ginger based agroforestry system was Tk. $158250 \mathrm{ha}^{-1}$ and 181290 $\mathrm{ha}^{-1}$ for the year 2017 and 2018 respectively with a total yield of Tk. $339540 \mathrm{ha}^{-1}$ (Table 2). The benefitcost ratio (BCR) of the Lemon-Pineapple-PapayaGinger based agroforestry system was 2.785 which clearly indicated that this agroforestry system was much more profitable than sole cropping (Table 2). The result showed that the Land Equivalent Ratio (LER) during 2017-2018 of Lemon-Pineapple-Papaya-Ginger based agroforestry system was 1.60 indicated that this agroforestry system is profitable (Table 2). The calculated Net Present Value (NPV) and Benefit-Cost Ration (BCR) of the pineapple plantation were BDT 487010.79 and 5.35 respectively at $10 \%$ interest rate which indicated the maximum profitability of Pineapple agroforestry practice in Madhupur Sal forest that reported by Rana (2010). Hanif et al. (2010) found that Litchi based agroforestry system ensured a higher return and more sustainable than sole cropping system. Kibira and Saha (2011) found that the Pineapple agroforestry is much more suitable than the other two agroforestry than lemon and banana-based agroforestry in the Madhupur Sal Forest.

Lemon-mango-turmeric-red amaranth based agroforestry system: From Table 2 it showed that the incurred cost of production for the cultivation of 1 ha land of the Lemon-Mango-Turmeric-Red amaranth based agroforestry systems for the year of 2017 and 
2018 was Tk. 71560 and Tk. 31066 respectively where the initial cost of establishment of the this agroforestry system was the highest of Tk. 71560 in 1st year this was reduced in the next year of production. According to the result of yield analysis, the total yield of 2017 and 2018 year of the Lemon-Mango-Turmeric-Red amaranth based agroforestry system was Tk. 121890 $\mathrm{ha}^{-1}$ and Tk. $148010 \mathrm{ha}^{-1}$ respectively with a total yield of Tk. 269900/ha (Table 2). The benefit-cost ratio (BCR) of the Lemon-Mango-Turmeric-Red amaranth based agroforestry system was 2.630 which clearly indicated that this agroforestry system was much more profitable than sole cropping (Table 2). The result also showed that the Land Equivalent Ratio (LER) calculated from 2017 and 2018 year of Lemon-MangoTurmeric-Red amaranth based agroforestry system was with an average of 1.59 (Table 2). In accordance with the obtained result of LER of Lemon-Mango-TurmericRed amaranth based agroforestry system, LER more than 1 indicated that this agroforestry system is profitable than monocropping. Similar results were observed by Rawat et al. (2002) for the Dendrocalamus strictus plantation in North India. Another study by Chakraborty et al. (2015) reported that farmers practicing agroforestry better off than those not practicing agroforestry, both socially and economically.

Lemon-litchi-papaya-banana based agroforestry system: The result of the study revealed that the incurred cost of production of 2017 and 2018 years of Lemon-Litchi-Papaya-Banana based agroforestry system was Tk. $64859 \mathrm{ha}^{-1}$ and Tk. $30294 \mathrm{ha}^{-1}$ respectively where the highest of Tk. $121731 \mathrm{ha}^{-1}$ in the year 2017 which was reduced in the next year 2018 (Tk. $61737 \mathrm{ha}^{-1}$ ) of production (Table 2). On the other hand, the result of yield analysis found that the total yield of 2017 and 2018 years of Lemon-Litchi-PapayaBanana based agroforestry system was Tk. $325130 \mathrm{ha}^{-1}$ and Tk. $318370 \mathrm{ha}^{-1}$ respectively with a total yield of Tk. $643500 \mathrm{ha}^{-1}$ (Table 2). From the results, it observed that the benefit-cost ratio (BCR) and Land Equivalent Ratio (LER) of Lemon-Litchi-Papaya-Banana based agroforestry system were 3.507 and 1.72 which revealed that this agroforestry system was profitable than sole cropping (Table 2). Hasan et al. (2008) found that the cost was very high due to inputs during the initial year in case of the agro-economic performance of the Jackfruit-Pineapple agroforestry system in the Madhupur tract. The benefits from the JackfruitPineapple agroforestry production system started in the second year of planting, which was Tk. 457449/ha. Sharma (2012) found that the benefit-cost ratio was higher (7.69) in Bamboo-Papaya agroforestry practices and followed by the Bamboo-Banana (6.56) based agroforestry practices in Sonitpur, Assam, India.

\section{Comparison of economic assessment of lemon based} agroforestry systems versus control (without lemon plant) systems: The result of the study revealed that the total cost of production, gross return and net return of Lemon-Mango-Pineapple-Papaya-Ginger, LemonPineapple-Papaya-Banana-Aroid, Lemon-PineapplePapaya-Ginger, Lemon-Mango-Turmeric-Red amaranth and Lemon-Litchi-Papaya-Banana based agroforestry systems was $\mathrm{Tkha}^{-1}$ 177090, 171150, 121935, 102626, 183468; Tkha $^{-1}$ 565500, 601550, 339540, 269900, 643500 and $\mathrm{Tkha}^{-1}$ 388410, 430400, 217935, 167274, 460032, respectively which were higher than their sole cropping (except lemon plant) (Table 3) because superior income was obtained when crops cultivation is associated with lemon than sole cropping. According to the results of the benefit-cost ratio analysis, it has been found that all the selected Lemon based agroforestry systems obtained higher BCR compare to their control (without lemon plant) systems which clearly indicates that all the selected agroforestry systems were economically more profitable than their control systems (Table 3). Bari et al. (2016) reported that maximum BCR (5.20) was found in the Litchi based agroforestry systems over sole cropping $(\mathrm{BCR}=4.38)$. The highest benefit-cost ratio (3.54) was recorded from coconut+guava based multistoried agroforestry which was higher than their sole cropping (1.65) observed by Bari and Rahim (2012) reported that the highest (3.54) benefit-cost ratio was calculated from Coconut + Guava based multistoried agroforestry which was higher than their sole cropping (1.65). Akter et al. (2020) studied on productivity analysis of timber and fruit tree-based 


\section{Economic assessment of lemon-based agroforestry}

agroforestry practices in the Madhupur Sal forest of Bangladesh and found that the selected agroforestry agroforestry systems in terms of their total benefits, net profit and BCR.

practices were more profitable than their non-

Table 3. Comparison of economic assessment of lemon-based agroforestry systems vs. control (no lemon plant) systems.

\begin{tabular}{|c|c|c|c|c|c|}
\hline Combinations & $\begin{array}{l}\text { Nature of } \\
\text { combination }\end{array}$ & $\begin{array}{l}\text { Production } \\
\text { Cost } \\
(\mathrm{Tk} / \mathrm{ha})\end{array}$ & $\begin{array}{l}\text { Gross } \\
\text { Return } \\
(\mathrm{Tk} / \mathrm{ha})\end{array}$ & $\begin{array}{l}\text { Net } \\
\text { Return } \\
(\mathrm{Tk} / \mathrm{ha})\end{array}$ & BCR \\
\hline Lemon-Mango-Pineapple-Papaya-Ginger & Agroforestry & 177090 & 565500 & 388410 & 3.19 \\
\hline Mango-Pineapple-Papaya-Ginger & $\begin{array}{l}\text { Control (except } \\
\text { lemon plant) }\end{array}$ & 89530 & 231682 & 142530 & 2.59 \\
\hline Lemon-Pineapple-Papaya- Banana-Aroid & Agroforestry & 171150 & 601550 & 430400 & 3.51 \\
\hline Pineapple-Papaya-Banana-Aroid & $\begin{array}{l}\text { Control (except } \\
\text { lemon plant) }\end{array}$ & 95500 & 248500 & 153000 & 2.60 \\
\hline Lemon-Pineapple-Papaya- Ginger & Agroforestry & 121935 & 339540 & 217935 & 2.78 \\
\hline Pineapple-Papaya- Ginger & $\begin{array}{l}\text { Control (except } \\
\text { lemon plant) }\end{array}$ & 63750 & 153200 & 89450 & 2.40 \\
\hline Lemon-Mango-Turmeric-Red amaranth & Agroforestry & 102626 & 269900 & 167274 & 2.63 \\
\hline Mango-Turmeric-Red amaranth & $\begin{array}{l}\text { Control (except } \\
\text { lemon plant) }\end{array}$ & 49990 & 109270 & 59280 & 2.19 \\
\hline Lemon-Litchi-Papaya- Banana & Agroforestry & 183468 & 643500 & 460032 & 3.51 \\
\hline Litchi-Papaya-Banana & $\begin{array}{l}\text { Control (except } \\
\text { lemon plant) }\end{array}$ & 93260 & 203500 & 110240 & 2.18 \\
\hline
\end{tabular}

Selection of the best lemon based agroforestry systems: The results showed that BCR and LER of Lemon-Pineapple-Papaya-Banana-Aroid, LemonLitchi-Papaya-Banana, Lemon-Mango-PineapplePapaya-Ginger, Lemon-Pineapple-Papaya-Ginger, and
Lemon-Mango-Turmeric-Red amaranth based agroforestry system were $3.515,3.507,3.193,2.785$, 2.630 and $1.73,1.72,1.62,1.60,1.59$, respectively (Table 4).

Table 4. Selection of the best lemon-based agroforestry systems with respect to BCR and LER.

\begin{tabular}{|l|l|l|c|}
\hline Agroforestry systems & BCR & LER & Ranking \\
\hline Lemon-Pineapple-Papaya-Banana-Aroid & 3.515 & 1.73 & $1^{\text {st }}$ \\
\hline Lemon-Litchi-Papaya-Banana & 3.507 & 1.72 & $2^{\text {nd }}$ \\
\hline Lemon-Mango-Pineapple-Papaya-Ginger & 3.193 & 1.62 & $3^{\text {rd }}$ \\
\hline Lemon-Pineapple-Papaya-Ginger & 2.785 & 1.60 & $4^{\text {th }}$ \\
\hline Lemon-Mango-Turmeric-Red amaranth & 2.630 & 1.59 & $5^{\text {th }}$ \\
\hline
\end{tabular}


Among the selected lemon-based agroforestry systems, it has been found that Lemon-Pineapple-PapayaBanana-Aroid based agroforestry system was most profitable having BCR of 3.515 and LER 1.73 followed by Lemon-Litchi-Papaya-Banana $>$ LemonMango-Pineapple-Papaya-Ginger $>$ Lemon-PineapplePapaya-Ginger $>\quad$ Lemon-Mango-Turmeric-Red amaranth based agroforestry systems (Table 4). The study also revealed that the highest economic benefit, as well as resource conservation, is possible when crops are associated with different tree species rather than a monoculture.

\section{Conclusion}

From the result of the study, it has been found that the gross return and net return of the Lemon-LitchiPapaya-Banana based agroforestry system was financially more profitable than other lemon-based agroforestry systems. While BCR and LER were higher in Lemon-Pineapple-Papaya-Banana-Aroid based agroforestry system which indicates that this lemon-based agroforestry system was more economically productive than other selected lemonbased agroforestry systems. Moreover, it has been found that all of the selected lemon-based agroforestry systems were profitable than their sole cropping in respect of returns, BCR and LER. Therefore, it can be concluded that the amount of components available in the system has a direct effect on economic productivity as well as the presence of lemon also increases the overall yield of respective lemon-based agroforestry systems.

\section{Acknowledgments}

This study was funded by National Agricultural Technology Program-2 (NATP-2) under the competitive research grant (CRG) of Bangladesh Agricultural Research Council (BARC). We thank the project members of $\mathrm{CRG}$ for their valuable suggestions during the field study.

\section{References}

Akter R, Hasan MK, Rahman GMM (2020). Productivity analysis of timber and fruit treebased agroforestry practices in Madhupur Sal forest, Bangladesh. Journal of Bangladesh Agricultural University, 18(1): 68-75.

Alam M, Furukawa Y, Harada K (2010). Agroforestry as a sustainable land-use option in degraded tropical forests: a study from Bangladesh. Environment, Development and Sustainability, 12(2): 147-158. https://doi.org/10.1007/s10668009-9186-3.

Alam MS, Haque MF, Abedin MZ, Akter S (1990). Homestead trees and household fuel uses in and around the farming systems research site, Jessore. In Homestead plantation and agroforestry in Bangladesh. edn. Abedin MZ, Lai CK, Ali MO. BARI, RWEDP and WINROCK, Joydebpur, Bangladesh. pp. 106-119.

Anshiso A, Woldeamanuel T, Asfaw Z (2017). Financial analysis of fruit tree-based agroforestry practice in Hadero Tunto Zuria Woreda, Kembata Tembaro Zone, South Ethiopia. Research Journal of Finance and Accounting, 8(3): 72-80.

BFD (Bangladesh Forest Department) (2017). Land and Forest area. Official website of Bangladesh Forest Department (FD), Government of Bangladesh.

Banglapedia (2015a). National Encyclopedia of Bangladesh. Forest and Forestry. http://en.banglapedia.org/index.php?title=Forest_ and_Forestry.

Banglapedia (2015b). National Encyclopedia of Bangladesh. Madhupur Upazila. http://en.banglapedia.org/index.php?title=Madhu pur_Upazila.

Bari MS, Rahim MA (2012). Economic evaluation and yield performance of some medicinal plants in coconut-based multistoried agroforestry systems. The Agriculturists, 10(1): 71-80. https://doi.org/10.3329/agric.v10i1.11067.

Bari MS, Zaman MR, Kajal M, Firoz HM (2016). Potentiality of litchi-fodder based agroforestry 
system in Bangladesh. Journal of Food and Nutrition Research, 4(2): 76-81.

BBS (Bangladesh Bureau of Statistics) (2014). Statistical Year Book of Bangladesh, Bangladesh Statistics Division, Ministry of Planning, Bangladesh Secretariat, The Government of the Peoples Republic of Bangladesh, Dhaka, Bangladesh.

Chakraborty M, Haider MZ, Rahman MM (2015). Socio-economic impact of cropland agroforestry: evidence from Jessore district of Bangladesh. International Journal of Research in Agriculture and Forestry, 2(1): 11-20.

FAO (Food and Agriculture Organization) (2015). World Food and Agriculture Statistical Year Book. Food and Agriculture Organization of the United Nations, Rome, Italy. http://www.fao.org/forestry/agroforestry/80338/e $\mathrm{n} /$.

Franzel S, Scherr SJ. (eds) (2002). Trees on the farm: assessing the adoption potential of agroforestry practices in Africa. CABI, Wallingford, UK. pp. 197.

Ghosh SR, Wadud MA, Mondol MA, Rahman GMM (2011). Optimization of plant density of Akashmoni (Acacia auriculiformis) for the production of fuelwood in the bunds of cropland. Journal of Agroforestry and Environment, 5(2): 1-6.

Hanif MA, Amin MHA, Bari MS, Ali MS, Uddin MN (2010). Performance of okra under litchi based agroforestry system. Journal of Agroforestry and Environment, 4(2): 137-139

Hasan M, Rahim MA, Islam AKMS, Rahman MM, Rahman MA, Naher N (2016). Effect of management practices on the growth and yield of lime and lemon. International Journal of Biosciences, 8(6): 22-33.

Hasan MK, Ahmed MM, Miah MG (2008). Agroeconomic performance of the jackfruit-pineapple agroforestry system in Madhupur Tract. Journal of Agriculture and Rural Development, 6(1): 147156.

Hasan MK, Karim MR (2020). Assessment of economic profitability and soil nutrient status of Eucalyptus and Gamar based agroforestry practices in the Madhupur Sal forest of Bangladesh. Journal of Agriculture, Food and Environment, 1(2): 73-85.

Islam KK, Jose $\mathrm{S}$, Tani M, Hyakumura K, Krott M, Sato N (2015). Does actor power impede outcomes in the participatory agroforestry approach? Evidence from the Sal forests area, Bangladesh. Agroforestry Systems, 89: 885-899.

Islam KK, Rahman GMM, Fujiwara T, Sato N (2013). People's participation in forest conservation and livelihoods improvement: experience from a forestry project in Bangladesh. International Journal of Biodiversity Science, Ecosystem Services and Management, 9(1): 30-43.

Islam KK, Ullah MO, Hoogstra M, Sato N (2012) Economic contribution of participatory Agroforestry program to poverty alleviation: a case from Sal forests, Bangladesh. Journal of Forestry Research, 23(2): 323-332.

Islam KK, Kimihiko H, Takahiro F, Sato N (2011) Confronting people-oriented forest management realities in Bangladesh: An analysis of actors' perspective. International Journal of Social Forestry, 4(2): 153-179.

Kibria MG. and Saha N (2011) Analysis of existing agroforestry practices in Madhupur Sal forests: an assessment based on ecological and economic perspectives. Journal of Forestry Research, 22(4): 533-542. https://doi.org/10.1007/s11676-0110196-2.

Rahman A, Rahman MA, Miah MG, Hoque A, Rahman M (2018). Productivity and profitability of jackfruit-eggplant agroforestry system in the terrace ecosystem of Bangladesh. Turkish Journal of Agriculture- Food Science and Technology, 6(2): 124-129.

Rahman MA, Bodiuzzaman M, Miah MA, Hossain MN, Rokanuzzaman M (2013). Causes of Deforestation and Conservation of Madhupur Sal Forest in the Tangail Region. Journal of Environmental Science and Natural Resources, 6(2): 109-114.

Rahman SA, Jacobsen JB, Healey JR, Roshetko JM, Sunderland $T$ (2017). Finding alternatives to swidden agriculture: does agroforestry improve 
livelihood options and reduce pressure on existing forest? Agroforestry Systems, 91: 185199.

Rana MT (2017). Productivity analysis of mango based agroforestry systems in the Madhupur Sal forest area. M.S. Thesis, Department of Agroforestry, Bangladesh Agricultural University, Mymensingh, Bangladesh. pp. 1-44.

Rawat JS, Singh TP, Rawat RBS (2002). Potential of bamboos in agroforestry in India. In: National Workshop on Policy and Legal Issues in Cultivation and Utilization of Bamboo, Rattan and Forest Trees on Private and Community Lands, Kerala, 7-9 August 2001. Proceedings, Peechi, KFRI, India. pp. 38-44.

Roy B, Rahman MH, Fardusi MJ (2011). Impact of banana-based agroforestry on degraded Sal forest (Shorea robusta C.F. Gaertn) of Bangladesh: a study from Madhupur National Park. Journal of Biodiversity and Ecological Sciences, 2(2): 6372.
Safa MS (2004). The effect of participatory forest management on the livelihood of the settlers in a rehabilitation program of degraded forest in Bangladesh. Small-scale Forest Economics, Management and Policy, 3(2): 223-238.

Sharma MK (2012). Final project report on development, evaluation and dissemination of technologies for improving productivity and production of the bamboo and bamboo-based cropping system. Assam Agriculture University, Assam, India. p. 20. 